\title{
Insulin-Like Growth Factor I in Substrate- Deprived, Growth-Retarded Fetal Rats
}

\author{
IRA M. BERNSTEIN, MARY M. DESOUZA, AND KENNETH C. COPELAND \\ Departments of Obstetrics and Gynecology and Pediatrics, University of Vermont College of Medicine, \\ Burlington, Vermont 05401
}

\begin{abstract}
Plasma, amniotic fluid, and tissue concentrations of IGF-I were examined in nutritionally deprived, growth-retarded fetal rats to determine whether IGF-I concentration serves as a marker for nutritional status. Growth retardation was induced by $72 \mathrm{~h}$ of maternal fasting. Twenty-three control and 17 growth-retarded fetuses were individually analyzed and compared. Plasma IGF-I concentrations were significantly lower in test compared with control animals (test $56.8 \pm 14.9$, control $87.4 \pm 17.5$ $\mathrm{ng} / \mathrm{mL}, p<0.01$ ). Amniotic fluid IGF-I concentrations were not different (test $14.0 \pm 8.7$, control $12.2 \pm 2.6 \mathrm{ng} /$ $\mathrm{mL}$ ). IGF-I concentrations obtained from both placenta and hepatic tissues were lower in test compared with control animals [placenta: test $293 \pm 25$ versus control 655 $\pm 114 \mathrm{ng} / \mathrm{g}(p<0.001)$; hepatic: test $173 \pm 38$ versus control $230 \pm 51 \mathrm{ng} / \mathrm{g}(p<0.01)$. Reductions in fetal, placental, and hepatic weights in test animals were more closely related to changes in placental IGF-I concentration than to either plasma or hepatic IGF-I concentrations. We conclude that fetal plasma IGF-I is a valuable marker for intrauterine substrate deprivation and that the growthretarded rat fetus is accurately identified and specifically characterized by a low placental concentration of extractable IGF-I. (Pediatr Res 30: 154-157, 1991)
\end{abstract}

Circulating concentrations of IGF-I are influenced by both growth hormone and nutritional status (1-10). Although the importance of IGF-I in the regulation of fetal growth has been explored, a central role for IGF-I in fetal growth has not been firmly established (4). Both IGF-I and its receptor have been found in multiple fetal tissues, suggesting an autocrine and/or paracrine mechanism of biologic action $(5,11-14)$. Based on its role as a marker of nutritional status, we hypothesized that fetal plasma and amniotic fluid concentrations of IGF-I would be depressed in nutritionally deprived, growth-retarded fetal rats. We also hypothesized that tissue concentrations of IGF-I would correlate best with the weights of the respective tissues of origin, consistent with an autocrine or paracrine mode of action.

\section{MATERIALS AND METHODS}

Animals. A maternal substrate deprivation model of fetal growth retardation was used $(10,15)$. Virgin Sprague Dawley rats $(240-280 \mathrm{~g})$ were used as experimental animals. Seven control and six test maternal animals were studied. Pregnancies were dated, with $\mathrm{d} 1$ representing the day on which vaginal sperm were identified after overnight mating. Test animals were fasted between $\mathrm{d} 18$ and 21 of gestation, but had full access to water.

Received August 20, 1990; accepted April 16, 1991.

Reprint requests: Ira M. Bernstein M.D., Department of Obstetrics and Gynecology, Shepardson 419 M.C.H.V., Burlington, VT 05401.
Control animals were allowed free access to both food and water. Sampling was performed on $\mathrm{d} 21$ in all animals, after intraperitoneal pentobarbital $(45 \mathrm{mg} / \mathrm{kg})$ administration. Midline laparotomy incision was used to expose the uterine horns. Fetuses in each horn were counted, and the two inferior fetuses of each horn were sampled to match the control and test group with regard to intrauterine location. A maximum of four fetuses per dam were analyzed to insure matching of uterine location between groups and to minimize any metabolic impact of the surgical procedure. Only those fetuses in whom results from all specimens were available were included in the analyses. The sampling sequence was initiated by the removal of amniotic fluid with a 19 - or 20 -gauge $1-\mathrm{mL}$ syringe. The fetus was then removed from its location in the uterine horn, and an axillary cutdown was performed (15). Fetal blood was collected by heparinized capillary tube, placed on ice, and centrifuged for 15 min at 12 $000 \times g$. The fetus was separated from the placenta, and the fetus, placenta, and then fetal liver were weighed. The placenta and liver were quickfrozen in liquid nitrogen. All samples were stored at $-80^{\circ} \mathrm{C}$ until analysis. After fetal sampling, a maternal venous plasma sample was obtained from the inferior vena cava just below the renal vein. Euthanasia was performed by means of exsanguination after all samples had been obtained. Individual fetal sex was identified and recorded. This study was approved by the University of Vermont Animal Care and Use Committee in accordance with N.I.H. guidelines.

Analyses. IGF-I concentrations in maternal and fetal plasma and amniotic fluid were determined by RIA [National Institute of Diabetes and Digestive and Kidney Diseases somatomedin-C antiserum (polyclonal) code no. UBK487 was a gift of Drs. Underwood and Van Wyck, University of North Carolina] after acid-chromatography (16). Fetal plasma $(0.025 \mathrm{~mL})$ was incubated with $0.2 \mathrm{M}$ glycine $\mathrm{HCl}(0.1 \mathrm{~mL}, \mathrm{pH} 2.0)$ at $37^{\circ} \mathrm{C}$ for $1 \mathrm{~h}$. After incubation, samples were added to a G-50 Sephadex column $(1.6 \times 41.0 \mathrm{~cm})$ and eluted at $25^{\circ} \mathrm{C}$ with $1 \mathrm{M}$ acetic acid $(\mathrm{pH} 2.5)$ at a flow rate of $60 \mathrm{~mL} / \mathrm{h}$. Two-mL fractions were collected, and absorbance at $280 \mathrm{~nm}$ was determined. The tubes corresponding to the free IGF-I fraction $\left(\mathrm{k}_{\mathrm{d}}=0.3-0.8\right)$ were pooled. A 1-mL aliquot of each pooled group was lyophilized to dryness. Aliquots were then washed with ammonium carbonate (1 mL, 0.025 M, pH 7.8) and relyophilized. The dried sample was then reconstituted in $0.15 \mathrm{~mL}$ of RIA buffer (without protamine) and frozen at $-80^{\circ} \mathrm{C}$ until assay.

Hepatic and placental IGF-I extractions were performed according to the method of D'Ercole and Underwood (17), with modifications as noted. Frozen tissue samples were placed in a porcelain mortar, covered with liquid nitrogen, and pulverized with a precooled pestle. The tissue powder was transferred to a tared disposable polystyrene centrifuge tube, and sample weight was recorded. Acetic acid (1.0M) was added $(5 \mathrm{~mL} / \mathrm{g}$ tissue), and the tubes were shaken for $15 \mathrm{~s}$, incubated on ice for $2 \mathrm{~h}$, and then centrifuged at $1000 \times g$ for $10 \mathrm{~min}$ at $4^{\circ} \mathrm{C}$. A $1.3-\mathrm{mL}$ aliquot was taken from each tube, neutralized with sodium hydroxide ( 5 $\mathrm{M} \mathrm{pH} 6-8)$ and frozen at $-80^{\circ} \mathrm{C}$ until assay. The contribution 
of tissue blood IGF-I in the hepatic and placental samples was calculated to represent less than $2 \%$ of the total IGF-I concentration in these exsanguinated and blotted tissue samples. This contribution was not corrected for in the analysis (17).

IGF-I concentrations in plasma and amniotic fluid were expressed as $\mathrm{ng} / \mathrm{mL}$ and tissue concentrations in $\mathrm{ng} / \mathrm{g}$ tissue dry weight after comparison with a pooled human serum standard. Aliquots of placental and liver extracts, as well as fetal and maternal sera, all displaced IGF-I tracer in parallel fashion to that observed with pure IGF-I standard (Imcera, Terre Haute, IN). Displacement of tracer binding by amniotic fluid could be achieved only at very high volumes, and the displacement curves showed slightly less parallelity to the pure standard.

Recovery of added cold IGF-I (Imcera) from placental extract, liver extract, fetal serum, maternal serum, and amniotic fluid, over a wide range of doses, were $59,79,66,67$, and $72 \%$, respectively.

Statistics. Mean somatic and tissue weights, amniotic fluid IGF-I concentrations, and both maternal and fetal plasma concentrations of IGF-I were compared by two-tailed unpaired $t$ test. Results are expressed as the mean \pm SD. $p$ values $\leq 0.05$ were accepted for significance.

\section{RESULTS}

Complete data sets were available on 23 control fetuses and 17 test fetuses. Growth retardation was successfully achieved with a significant reduction in hepatic, placental, and fetal weights of test animals compared with controls (Table 1). These differences could not be accounted for by a difference in prefast maternal weights, mean litter size, or the ratio of male to female fetuses within the groups (Table 2). The impact of $72 \mathrm{~h}$ of maternal fasting on IGF-I concentrations in the maternal plasma, fetal plasma, amniotic fluid, and fetal tissues is outlined in Table 3. Plasma IGF-I concentrations were reduced in both fasted dams and corresponding fetuses. Amniotic fluid IGF-I concentrations, however, were not different between test and control animals. Placental and hepatic tissue concentrations of IGF-I were lower in nutritionally deprived test fetuses.

The relationship between fetal weight and fetal plasma IGF-I

Table 1. Fetal morphometry

\begin{tabular}{lccc}
\hline & $\begin{array}{c}\text { Control } \\
(\text { mean } \pm \text { SD) }\end{array}$ & $\begin{array}{c}\text { Test } \\
(\text { mean } \pm \text { SD) }\end{array}$ & $p$ \\
\hline Fetal wt $(\mathrm{g})$ & $3.68 \pm 0.24$ & $2.76 \pm 0.19$ & $<0.001$ \\
Hepatic wt $(\mathrm{g})$ & $0.29 \pm 0.04$ & $0.17 \pm 0.03$ & $<0.001$ \\
Placental wt $(\mathrm{g})$ & $0.54 \pm 0.10$ & $0.43 \pm 0.07$ & $<0.01$ \\
Hepatic wt/Fetal wt & $0.08 \pm 0.01$ & $0.06 \pm 0.01$ & $<0.05$ \\
\hline
\end{tabular}

Table 2. Population characteristics

\begin{tabular}{lccc}
\hline & $\begin{array}{c}\text { Control } \\
(\text { mean } \pm \text { SD) }\end{array}$ & $\begin{array}{c}\text { Test } \\
(\text { mean } \pm \mathrm{SD})\end{array}$ & $p$ \\
\hline Maternal wt $(\mathrm{g})$ & & & \\
Day 1 & $261.2 \pm 13.2$ & $261.5 \pm 19.2$ & $\mathrm{NS}$ \\
Day 18 & $368.5 \pm 41.3$ & $345.0 \pm 27.0$ & $\mathrm{NS}$ \\
Day 21 & $407.0 \pm 43.0$ & $309.7 \pm 22.4$ & $<0.001$ \\
Litter size & $14.9 \pm 4.5$ & $14.0 \pm 1.3$ & $\mathrm{NS}$ \\
Fetal sex ratio (M/F) & 0.87 & 0.85 & $\mathrm{NS}$ \\
\hline
\end{tabular}

Table 3. IGF-I concentrations

\begin{tabular}{lccc}
\hline & $\begin{array}{c}\text { Control } \\
\text { (mean } \pm \mathrm{SD} \text { ) }\end{array}$ & $\begin{array}{c}\text { Test } \\
\text { (mean } \pm \text { SD) }\end{array}$ & $p$ \\
\hline Materal plasma IGF-I $(\mathrm{ng} / \mathrm{mL})$ & $345 \pm 100$ & $171 \pm 100$ & $<0.01$ \\
Fetal plasma IGF-I $(\mathrm{ng} / \mathrm{mL})$ & $87.4 \pm 17.5$ & $56.8 \pm 14.9$ & $<0.01$ \\
Amniotic fluid IGF-I $(\mathrm{ng} / \mathrm{mL})$ & $12.2 \pm 2.6$ & $14.0 \pm 8.7$ & $\mathrm{NS}$ \\
Hepatic IGF-I $(\mathrm{ng} / \mathrm{g})$ & $230 \pm 51$ & $173 \pm 38$ & $<0.01$ \\
Placental IGF-I $(\mathrm{ng} / \mathrm{g})$ & $655 \pm 114$ & $293 \pm 25$ & $<0.001$ \\
\hline
\end{tabular}

is illustrated in Figure 1. Maternal starvation resulted in a marked reduction in both fetal weight and fetal plasma IGF-I, although approximately $40 \%$ of the treated fetuses had plasma IGF-I levels overlapping with the controls. Figures 2 and 3 illustrate the same reduction in fetal weight relative to hepatic and placental tissue concentrations of IGF-I. As with the fetal plasma IGF-I concentrations, significant overlap was observed in hepatic IGF-I concentrations between control and test groups (Fig. 2). Figure 3 shows the relationship between fetal weights and placental IGF-

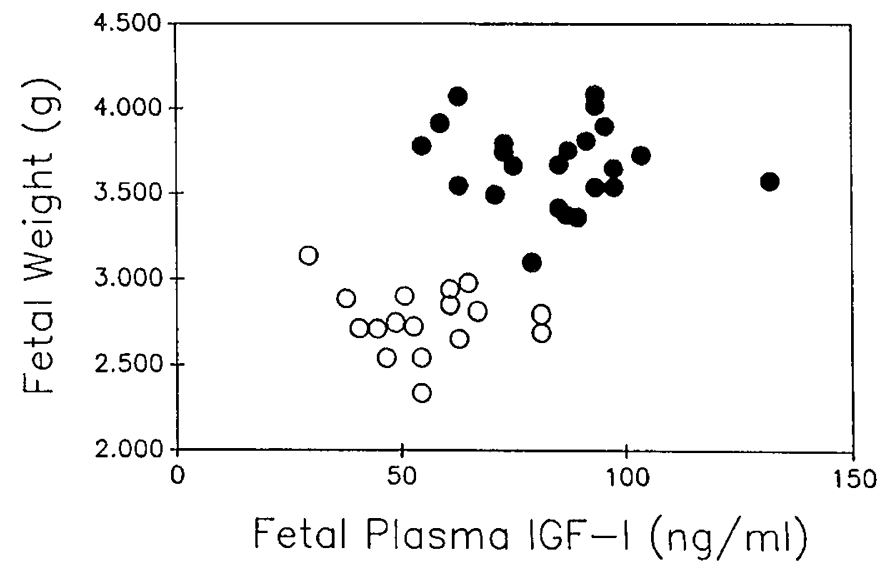

Fig. 1. Fetal plasma IGF-I concentration plotted against fetal weight for normally grown control (filled circles) and growth-retarded (open circles) fetal rat pups.

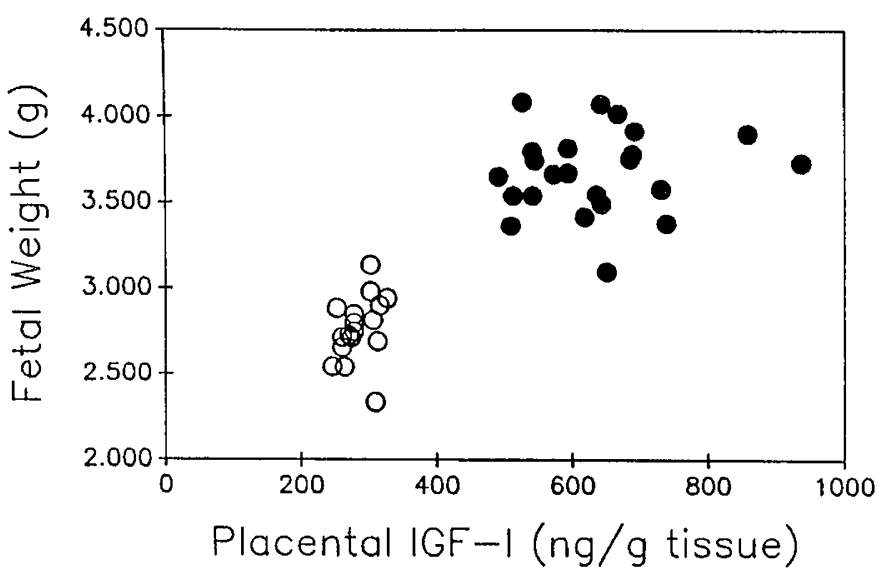

Fig. 2. Placental IGF-I concentration plotted against fetal weight for normally grown control (filled circles) and growth-retarded (open circles) fetal rat pups.

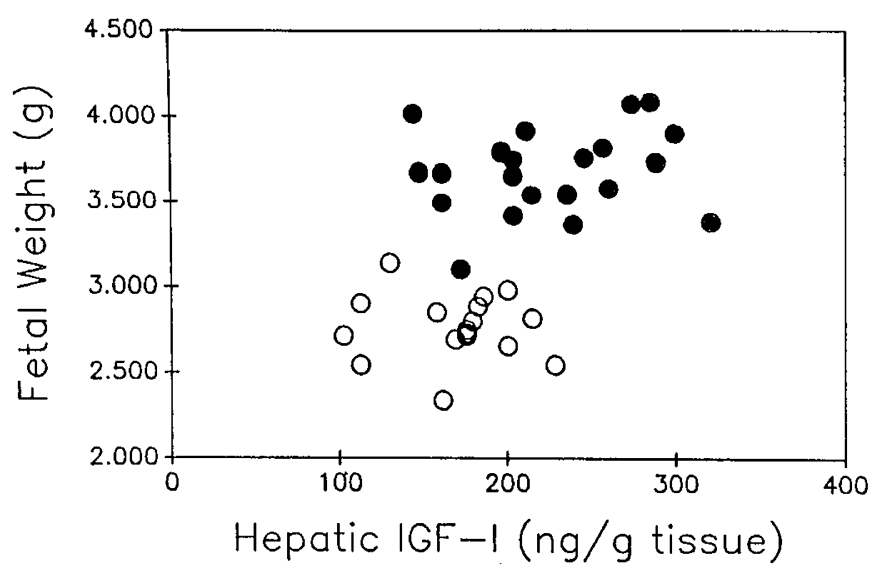

Fig. 3. Hepatic IGF-I concentration plotted against fetal weight for normally grown control (filled circles) and growth-retarded (open circles) fetal rat pups. 
I concentrations. As illustrated, a potent treatment effect was seen in both fetal weight and placental IGF-I concentration. Mean fetal weight was reduced by $25 \%$, whereas mean placental IGF-I concentration was reduced by $55 \%$. No overlap in IGF-I concentrations was observed among treated and control animals, even though one control fetus had a weight that overlapped with those of the treated fetuses.

Figure 4 demonstrates the relationship between hepatic weight and placental tissue concentrations of IGF-I. As shown, hepatic weights were markedly reduced in treated animals, although one control fetus had a hepatic weight falling within the range of those of the treated fetuses. The clear treatment effect on placental IGF-I is again apparent, with little overlap among hepatic weights. Once again, data from a single control fetus overlapped with those of the treated animals. The hepatic size of this fetus fell outside the lower range of those of the remaining control fetuses and close to the mean of the test animals. The hepatic and placental tissue concentrations of IGF-I for this animal, however, fell near to the mean for the control animals and outside the range of the test animals.

Figure 5 demonstrates the relationship between placental weight and placental tissue concentrations of IGF-I. Although the mean placental weight of treated animals was $20 \%$ less than that of the controls (Table 1), there was marked overlap of placental weight between control and test groups. And although the mean placental weight of treated animals was reduced by only $20 \%$ compared with that of controls, mean placental IGF-I tissue concentration was reduced by $55 \%$ (Table 3 ), with no overlap seen in individual IGF-I values between treated and control animals.

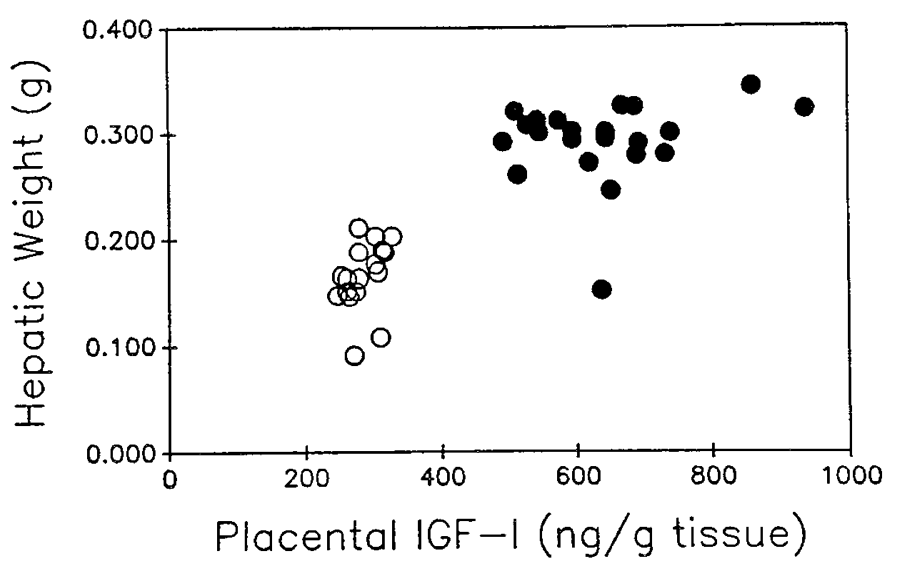

Fig. 4. Placental IGF-I concentration plotted against hepatic weight for normally grown control (filled circles) and growth-retarded (open circles) fetal rat pups.

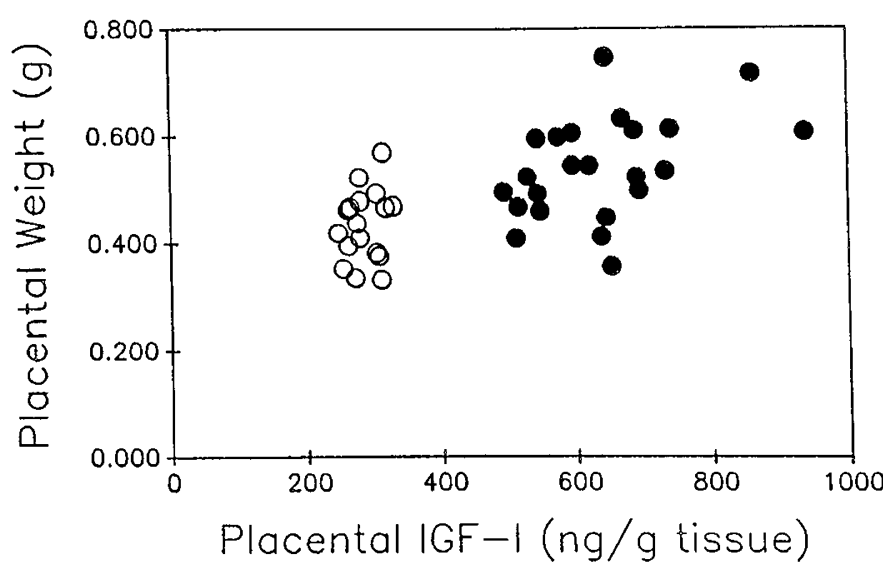

Fig. 5. Placental IGF-I concentration plotted against placental weight for normally grown control (filled circles) and growth-retarded (open circles) fetal rat pups.

\section{DISCUSSION}

Although IGF-I is felt to be a primary regulator of growth in postnatal life, its role during fetal life is unclear. Although IGF-I concentrations in postnatal life are directly influenced by growth hormone, other factors, including human placental lactogen and prolactin, may be operative in utero $(7,18)$. IGF-I levels in blood have been shown to reflect changes in nutritional balance and have been proposed as markers for nutritional status (19). In this study, we used a rat maternal starvation model, both to examine the utility of plasma and amniotic fluid IGF-I concentrations as markers of suboptimal nutrition and to evaluate the relationship between IGF-I concentrations and fetal somatic and tissue growth. The model used effectively resulted in a reduction in hepatic, placental, and overall fetal size. Analysis of the hepatic weight/fetal weight ratio revealed an asymmetric form of growth retardation; that is, the reduction in hepatic weights was proportionately greater than the overall reductions in fetal weights (Table 1). Significant reductions in IGF-I concentrations were noted in all compartments studied with the exception of amniotic fluid. It is unclear why amniotic fluid IGF-I concentrations failed to coincide with the plasma and tissue levels in this model. Assuming that amniotic fluid IGF-I is of fetal origin, then the lack of responsiveness of IGF-I to acute maternal substrate deprivation may reflect a pool that is slowly responsive to acute perturbations of fetal nutritional status. Alternatively, it may be that G-50 acid chromatography does not adequately separate IGF-I from the amniotic fluid binding protein, and thus does not accurately reflect the state of IGF-I in the amniotic fluid compartment under conditions of suboptimal nutrition $(20,21)$.

The changes observed in IGF-I in this study are consistent with previous data evaluating changes in IGF-I in the growthretarded fetus and in early postnatal life $(8-10,22)$. Fetal rat pups rendered growth-retarded by uterine artery ligation were found to have depressed serum and tissue levels of IGF-I when compared with controls (9). Similarly, 10-d-old rat pups deprived of calories for $24 \mathrm{~h}$ showed significant reductions in serum levels of IGF-I, although no significant effects on hepatic IGF-I concentrations were found (8). Our results show absolute plasma IGF-I values in control and intrauterine growth-retarded animals similar to those reported previously, although the hepatic concentrations were approximately 10 -fold higher than those previously reported using similar methodology (9). This discrepancy may reflect inherent differences in hepatic IGF-I concentration induced by uterine artery ligation compared with maternal substrate deprivation.

Associations between placental IGF-I concentrations and indices of fetal growth retardation have not been previously reported. It should be noted that most placental tissue samples contain a small amount of maternal decidua. Although IGF-I is extractable from maternal decidua (unpublished observation), the relative contribution of maternal tissue to the samples obtained is small. It therefore seems unlikely that maternal IGF-I contributed significantly to the IGF-I concentrations obtained from the placental tissue samples.

In our current study, IGF-I levels from growth-retarded fetuses were not only depressed in blood, but also in various tissue compartments. Some observations, however, were unanticipated. Previous studies have suggested that the majority of circulating IGF-I is of hepatic origin (23). In the present study, the absolute levels of IGF-I in the placenta were more than 2.5 -fold higher than hepatic levels in the fed state and approximately $75 \%$ higher than hepatic levels in the substrate-deprived state. The significance of this observation is unclear. Fant et al. $(13,24)$ suggested that persistent placental IGF-I production through term lends support for an autocrine/paracrine mode of IGF-I action. However, inasmuch as previous studies have demonstrated that both DNA expansion and placental growth are complete well before term $(25,26)$, the relatively high concentrations of IGF-I in placental tissue (as noted in the control animals) suggest a 
discordance between placental growth and placental IGF-I production. Furthermore, we observed that in test animals a reduced placental IGF-I concentration was closely associated with fetal and hepatic growth retardation, independent of the size of the corresponding placenta. Together these observations suggest that, if placental IGF-I is involved in fetal growth, then it is functioning at least in part in classic endocrine as opposed to autocrine or paracrine fashion.

IGF-I appears to be involved in the growth and differentiation of fetal tissues (4). Recent evidence, however, suggests that the biologic action of IGF-I is strongly modified by the relative concentrations of its binding proteins in plasma, amniotic fluid, and a variety of tissues $(27-32)$. Thus, a measurement in blood or tissue of the IGF-I concentration after removal of the binding proteins gives only one index of the biologic action of this growth factor. Nevertheless, the strong associations between IGF-I and fetal and tissue size observed in this study suggest that IGF-I may indeed be involved in fetal growth.

Together, these data suggest that IGF-I concentrations in fetal plasma, as well as those obtained from hepatic and placental tissue, serve as valuable markers for fetal growth retardation induced by maternal substrate deprivation. In contrast to IGF-I obtained from plasma or hepatic tissue, however, IGF-I obtained from placental tissue appears to reflect fetal and hepatic growth with high degrees of accuracy and specificity. Because placental size is not associated with placental IGF-I concentration, whereas fetal size and placental IGF-I appear closely associated, one can speculate that the placenta is involved in the regulation of fetal growth, in part through the production and dispersion of IGF-I in classic endocrine fashion.

\section{REFERENCES}

1. Chard T 1989 Hormonal control of growth in the fetus. J Endocrinol 123:3-9

2. Underwood LE, Clemmons DR, Maes, M, D'Ercole J, Ketelslegers JM 1986 Regulation of somatomedin-C/insulin-like growth factor I by nutrients. Horm Res 24:166-176

3. Phillipps A, Drakenberg K, Persson B, Sjoren B, Eklof C, Hall K, Sara V 1989 The effects of altered nutritional status upon insulin-like growth factors and their binding proteins in neonatal rats. Pediatr Res 26:128-134

4. D'Ercole J 1987 Somatomedins/insulin-like growth factors and fetal growth. J Dev Physiol 9:481-495

5. D'Ercole AJ, Stiles AD, Underwood LE 1984 Tissue concentrations of somatomedin C: further evidence for multiple sites of synthesis and paracrine or autocrine mechanism of action. Proc Natl Acad Sci USA 81:935-939

6. Bassett NS, Oliver MH, Breier BH, Gluckman PD 1990 The effect of maternal starvation on plasma insulin-like growth factor I concentrations in the late gestation ovine fetus. Pediatr Res 27:401-404

7. Pilistine SJ, Moses AC, Munro HN 1984 Placental lactogen administration reverses the effect of low-protein diet on maternal and fetal serum somatomedin levels in the pregnant rat. Proc Natl Acad Sci USA 81:5853-5857

8. Philipps A, Drakenberg K, Persson B, Sjogren B, Eklof AC, Hall K, Sara V 1989 The effects of altered nutritional status upon insulin-like growth factors and their binding proteins in neonatal rats. Pediatr Res 26:128-134

9. Vilesis RA, D'Ercole AJ 1986 Tissue and serum concentrations of somatomedin-C/insulin-like growth factor I in fetal rats made growth retarded by uterine artery ligation. Pediatr Res 20:126-130

10. Davenport ML, D'Ercole AJ, Underwood LE 1990 Effect of maternal fasting on fetal growth, serum insulin-like growth factors (IGFs), and tissue IGF messenger ribonucleic acids. Endocrinology 126:2062-2067

11. D'Ercole AJ, Applewhite GT, Underwood LE 1980 Evidence that somatomedin is synthesized by multiple tissues in the fetus. Dev Biol 75:315-328
12. Hill DJ, Clemmons DR, Wilson S, Han VKM, Strain AJ, Milner RDG 1989 Immunologic distribution of one form of insulin like growth factor (IGF)binding protein and IGF peptides in human fetal tissues. J Mol Endocrinol 2:31-38

13. Fant ME, Munro H, Moses AC 1986 An autocrine/paracrine role for the insulin-like growth factors in the regulation of human placental growth. $J$ Clin Endocrinol Metab 63:499-505

14. Hill DJ 1990 Relative abundance and molecular size of immunoreactive insulin-like growth factors I and II in human fetal tissues. Early Hum Dev 21:49-58

15. Girard JR, Ferre P, Gilbert M, Kervran A, Assan R, Marliss E 1977 Fetal metabolic response to maternal fasting in the rat. Am J Physiol 232:E456463

16. Copeland KC, Johnson DM, Underwood LE, Van Wyk JJ 1983 Radioimmunoassay of somatomedin $\mathrm{C}$ in the baboon (Papio cynocephalus): a comparison of multiple techniques of measurement. Am J Primatol 5:161169

17. D'Ercole AJ, Underwood LE 1987 Estimation of tissue concentrations of somatomedin C/insulin-like growth factor I. Methods Enzymol 146:227233

18. Hill DJ, Freemark M, Strain AJ, Handwerger S, Milner RDG 1988 Placental lactogen and growth hormone receptors in human fetal tissues: relationship to fetal plasma human placental lactogen concentrations and fetal growth. $\mathbf{J}$ Clin Endocrinol Metab 66:1283-1290

19. Phillips LS, Unterman TG 1984 Somatomedin activity in disorders of nutrition and metabolism. Clin Endocrinol Metab 13:145-189

20. Drop SL, Kortleve DJ, Guyda HJ 1984 Isolation of a somatomedin binding protein from preterm amniotic fluid. Development of a radioimmunoassay. J Clin Endocrinol Metab 59:899-907

21. Drop SLS, Valiquette C, Guyda HJ, Corvol MT, Posner BI 1979 Partial purification and characterization of a binding protein for insulin like activity in human amniotic fluid. A possible inhibitor of insulin like activity. Acta Endocrinol (Copenh) 90:505-518

22. Philipps AF, Persson B, Hall K, Lake M, Skottner A, Sanengen T, Sara V 1988 The effects of biosynthetic insulin-like growth factor I supplementation on somatic growth, maturation and erythropoiesis on the neonatal rat. Pediatr Res 23:298-305

23. Nissley SP, Rechler MM 1984 Insulin-like growth factors: biosynthesis receptors and carrier proteins. In: $\mathrm{Li} \mathrm{C}$ (ed) Hormonal Proteins and Peptides. Academic Press, New York, pp 127-203

24. Fant M, Munro H, Moses AC 1988 Production of insulin-like growth factor binding proteins by human placenta: variation with gestational age. Placenta 9:397-407

25. Winick M, Noble A 1966 Quantitative changes in ribonucleic acid and protein during normal growth of rat placenta. Nature 212:34-35

26. Winick M, Coscia A, Noble A 1967 Cellular growth in human placenta. Pediatrics 39:248-251

27. Hardouin S, Gourmelen M, Noguiez P, Seurin D, Roghani M, Le Bouc Y, Povoa G, Merimee TJ, Hossenlopp P, Binoux M 1989 Molecular forms of serum insulin-like growth factor-binding proteins in man: relationships with growth hormone and IGFs and physiological significance. J Clin Endocrinol Metab 69:1291-1301

28. Blum WF, Jenne EW, Reppin F, Kietzmann K, Ranke MB, Bierich JR 1989 Insulin-like growth factor I binding protein complex is a better mitogen than free IGF-I. Endocrinology 125:766-772

29. Ranke MB, Blum WF, Bierich JR 1988 Clinical relevance of serum measurements of insulin-like growth factors and somatomedin binding proteins. Acta Paediatr Scand 347(suppl): 1 14-126

30. Hill DJ, Camacho-Hubner C, Rashid P, Strain AJ, Clemmons DR 1989 Insulin-like growth factor (IGF)-binding protein release by human fetal fibroblasts: dependency on cell density and IGF peptides. J Endocrinol 122:87-98

31. Hardouin S, Hossenlopp P, Segovia B, Seurin D, Portolan G, Lassarre C, Binoux M 1987 Heterogeneity of insulin-like growth factor binding proteins and relationship between structure and affinity. 1. Circulating forms in man. Eur J Biochem 170:121-132

32. Elgin RG, Busby WH, Clemmons DR 1987 An insulin-like growth factor (IGF) binding protein enhances the biologic response to IGF-I. Proc Natl Acad Sci USA 84:3254-3258 